\title{
Content of biogenic and toxic elements in the leaves of Deschampsia antarctica É. Desv. (Poaceae): a preliminary study
}

\author{
(1) T. Bedernichek 1*, (1) V. Loya 1, 이. Parnikoza ${ }^{2,3}$ \\ 1 M.M. Gryshko National Botanical Garden, National Academy of Sciences of Ukraine, Timiryazevska str. 1, 01014 Kyiv, Ukraine; \\ * bedernichek@nas.gov.ua \\ ${ }^{2}$ National Antarctic Scientific Center of Ukraine, Tarasa Shevchenka blvd. 16, 01601 Kyiv, Ukraine \\ ${ }^{3}$ Institute of Molecular Biology and Genetics, National Academy of Sciences of Ukraine, Acad. Zabolotnogo str. 150, 03143 Kyiv, \\ Ukraine
}

Received: 06.05.2020 | Accepted: 05.06.2020 | Published: 30.06.2020

\begin{abstract}
The Antarctic hairgrass (Deschampsia antarctica É. Desv.) is one of two flowering plants native to the Antarctic, and therefore it was intensively studied for decades. However, there is still limited information available about the content of biogenic and toxic elements in the leaves of this plant. While being an essential component of most of the terrestrial ecosystems in the maritime Antarctic, the content of nutrients like $\mathrm{K}, \mathrm{P}$, and $\mathrm{S}$ in the plants of $\mathrm{D}$. antarctica may significantly affect soil properties, especially in such hot spots like rhizosphere and detritosphere. Moreover, the content of toxic elements and trace metals, in particular in the plant, is a principal criterion to evaluate its indicative role, whether or not $D$. antarctica may be used as a bioindicator to monitor the Antarctica environmental state. In this study, we report the preliminary results about the content of $\mathrm{K}, \mathrm{P}, \mathrm{Ca}, \mathrm{S}, \mathrm{Mg}, \mathrm{Na}, \mathrm{Si}, \mathrm{Fe}, \mathrm{Zn}, \mathrm{Al}, \mathrm{Sr}, \mathrm{Mn}, \mathrm{Cu}, \mathrm{B}, \mathrm{Cr}$, $\mathrm{Ba}, \mathrm{V}, \mathrm{Pb}, \mathrm{Cd}$, and $\mathrm{Co}$ in the leaves of $\mathrm{D}$. antarctica from the natural habitats of the maritime Antarctic. Dry leaves were digested in nitric acid (closed-vessel microwave digestion). Elemental concentration was measured by ICP-OES technique. The differences within the samples taken from one location were far less notable than between the samples from different locations. Among the biogenic elements, the content of potassium was the most variable - from $12.2 \mathrm{mg} \cdot \mathrm{g}^{-1}$ on Galindez Island to $28.7 \mathrm{mg} \cdot \mathrm{g}^{-1}$ on the Cape Tuxen (Antarctic Peninsula). The content of trace metals also varied considerably between the samples from different locations. The results of this preliminary study suggest that due to the high content of nutrients, leaves of $D$. antarctica should be considered as an important precursor of soil organic matter, as well as a possible bioindicator. However, future studies are needed to confirm these preliminary results and hypotheses.
\end{abstract}

Keywords: Antarctic hairgrass, nutrients, trace metals, toxic elements

\section{Introduction}

The Antarctic hairgrass (Deschampsia antarctica É. Desv.) is one of two flowering plants native to the Antarctic, and therefore it was intensively studied for decades. Most studies were concerned with $D$. antarctica adaptations to the harsh conditions of the Antarctic and its genetic and molecular aspects (Gidekel et al., 2003; Chwedorzewska et al., 2008; Parnikoza, 2019), phylogeography and evolution (Fowbert \& Lewis Smith, 1994; Chiapella, 2007; Fasanella et al., 2017), in vitro conservation (Cuba-Díaz et al., 2020). D. antarctica is a perennial plant with origin not clearly known yet; however, most of the studies conclude that Antarctic vascular plant 
species have reached the Antarctic on a recent (mid to late Pleistocene) timescale (Parnikoza et al., 2011; Fasanella et al., 2017; Biersma et al., 2020). Populations of this species inhabit territories with diverse conditions, both with poor soils and fertile soils near the colonies of birds and mammals. In maritime Antarctic, D. antarctica populations had low genetic diversity and high morphological and anatomical variability (Ozheredova et al., 2015; Chwedorzewska et al., 2008; Nuzhyna et al., 2019). Numerous studies were conducted to understand the specific mechanisms of D. antarctica plant adaptations to the low temperatures under enhanced UV-radiation. Most of them were focused on cytology, anatomy, physiological and biochemical characteristics, especially proteins, enzymes, lipids, and pigments (Parnikoza et al., 2011). While some information about the chemical composition of other plant species in the Antarctic is available (Fabiszewski \& Wojtun, 2000; Parnikoza et al., 2016), there is still limited data about the content of biogenic and toxic elements in the leaves of D. antarctica. Only a few studies focused specifically on this issue (Walton \& Smith, 1979; Fabiszewski \& Wojtun, 2000; Juchnowicz-Bierbasz \& Rakusa-Suszczewski, 2002). The objectives of this study were: to determine the content of biogenic and toxic elements in the leaves of D. antarctica from the vicinity of Akademik Vernadsky station (Argentine Islands, Wilhelm Archipelago), and to investigate whether the differences within the samples from one location were as notable as between samples from different locations.

\section{Material and methods}

Leaves of D. antarctica were sampled in 2016/2017 Antarctic summer season at four locations in the maritime Antarctic: Great Yalour Island $\left(65^{\circ} 14^{\prime} 08^{\prime \prime} \mathrm{S}, 64^{\circ} 09^{\prime} 22^{\prime \prime} \mathrm{W}\right)$, Galindez Island $\left(65^{\circ} 14^{\prime} 43^{\prime \prime} \mathrm{S}, 64^{\circ} 15^{\prime} 07^{\prime \prime} \mathrm{W}\right)$, Oasis Rasmussen $\left(65^{\circ} 14^{\prime} 49^{\prime \prime} \mathrm{S}, 64^{\circ} 05^{\prime} 10^{\prime \prime} \mathrm{W}\right)$ and Cape Tuxen $\left(65^{\circ} 16^{\prime} 11^{\prime \prime} \mathrm{S}, 64^{\circ} 07^{\prime} 09^{\prime \prime} \mathrm{W}\right)$. Two mixed samples from each location were taken. Visually similar plants were sampled at each site. Neither size nor color of these plants differed significantly. They were airdried and transported to the laboratory in zip-bags to avoid contamination. Before the analysis, samples were dried at a temperature of $105^{\circ} \mathrm{C}$ overnight. $500 \mathrm{mg}$ of each sample was digested in nitric acid, closed-vessel microwave digestion, Wu et al. (1997). Elemental concentration was measured by ICP-OES technique with the iCAP 6300 Duo Spectrometer (Thermo Fisher Scientific) at the M.M. Gryshko National Botanical Garden. This method enables fast and accurate measurements of multi-element profiles (Hansen et al., 2013). Content of K, P, Ca, S, $\mathrm{Mg}, \mathrm{Na}, \mathrm{Si}, \mathrm{Fe}, \mathrm{Zn}, \mathrm{Al}, \mathrm{Sr}, \mathrm{Mn}, \mathrm{Cu}, \mathrm{B}, \mathrm{Cr}, \mathrm{Ba}, \mathrm{V}$, $\mathrm{Pb}, \mathrm{Cd}$, and $\mathrm{Co}$ was determined. The chemical composition of the leaves was provided in dry matter. Unfortunately, we did not have enough plant material to determine the content of carbon and nitrogen, and this should be performed in future research.

\section{Results}

Leaves of D. antarctica contained a lot of biogenic elements. Park et al. (2007) reported that the carbon content in this plant was about $44 \%$, and the content of nitrogen about $2.5 \%$. We found out that the content of $\mathrm{K}$ was also relatively high - about $18.9 \pm 5.9$ $\mathrm{mg} \cdot \mathrm{g}^{-1}$. As can be seen from the Table 1 , the leaves of $D$. antarctica were also rich in $\mathrm{P}\left(4.9 \pm 1.8 \mathrm{mg} \cdot \mathrm{g}^{-1}\right), \mathrm{Ca}\left(4.3 \pm 0.5 \mathrm{mg} \cdot \mathrm{g}^{-1}\right), \mathrm{S}$ $\left(3.7 \pm 0.7 \mathrm{mg} \cdot \mathrm{g}^{-1}\right)$ and $\mathrm{Mg}\left(2.1 \pm 0.6 \mathrm{mg} \cdot \mathrm{g}^{-1}\right)$. The considerable differences in the chemical composition of the leaves were observed between the samples from different locations. Meanwhile, differences within the samples taken from one site tended to be less notable. For example, the content of potassium in the leaves sampled on Oasis Rasmussen, Great Yalour Island, and Galindez Island varied from 12.2 to $18.8 \mathrm{mg} \cdot \mathrm{g}^{-1}$ but was much higher in the samples from Cape Tuxen $\left(27.1-28.8 \mathrm{mg} \cdot \mathrm{g}^{-1}\right)$. Fabiszewski \& Wojtun (2000) reported that in the shoots of D. antarctica sampled at three different locations on King George Island content of Ca varied from 2.98 to $4.71 \mathrm{mg} \cdot \mathrm{g}^{-1}$, $\mathrm{Mg}$ from 1.46 to $2.21 \mathrm{mg} \cdot \mathrm{g}^{-1}$ and $\mathrm{K}$ from 5.26 to $9.10 \mathrm{mg} \cdot \mathrm{g}^{-1}$. Their results are similar to what we have found in this study. The exception is the content of $\mathrm{K}$, which was much lower in the plants from King George Island. This fact possibly reflects the different success of D. antarctica depending on the substrate, climate, and other factors. 
Table 1. Content of some essential and toxic chemical elements in the leaves of Deschampsia antarctica, $\mathrm{mg} \cdot \mathrm{kg}^{-1} \mathrm{DW}$.

\begin{tabular}{|c|c|c|c|c|c|c|c|c|c|}
\hline \multirow{2}{*}{$\begin{array}{l}\text { Chemical } \\
\text { elements }\end{array}$} & \multicolumn{2}{|c|}{ Oasis Rasmussen } & \multicolumn{2}{|c|}{ Great Yalour Island } & \multicolumn{2}{|c|}{ Cape Tuxen } & \multicolumn{2}{|c|}{ Galindez Island } & \multirow{2}{*}{ Mean \pm SD } \\
\hline & Sample 1 & Sample 2 & Sample 1 & Sample 2 & Sample 1 & Sample 2 & Sample 1 & Sample 2 & \\
\hline K & 15430 & 18780 & 16680 & 16080 & 28750 & 27100 & 12150 & 16030 & $18875 \pm 5892$ \\
\hline $\mathrm{P}$ & 6661 & 6781 & 2805 & 2892 & 6519 & 6010 & 3647 & 3904 & $4902 \pm 1752$ \\
\hline $\mathrm{Ca}$ & 5185 & 4735 & 4855 & 3841 & 4185 & 4285 & 4071 & 3576 & $4342 \pm 543$ \\
\hline S & 4364 & 4570 & 2992 & 3094 & 4113 & 4004 & 3134 & 2956 & $3653 \pm 675$ \\
\hline $\mathrm{Mg}$ & 2855 & 2965 & 2057 & 1882 & 2227 & 2242 & 1288 & 1271 & $2098 \pm 627$ \\
\hline $\mathrm{Na}$ & 872.6 & 722 & 1108 & 1253 & 563.3 & 528.6 & 747.2 & 781.4 & $822.0 \pm 251$ \\
\hline $\mathrm{Si}$ & 250.4 & 227.1 & 350.6 & 538.2 & 317.3 & 397.4 & 612.5 & 533 & $403.3 \pm 143$ \\
\hline $\mathrm{Fe}$ & 145.2 & 137.5 & 187.9 & 151.6 & 127.4 & 129.8 & 210.8 & 215.8 & $163.3 \pm 36.2$ \\
\hline $\mathrm{Zn}$ & 95 & 118.2 & 78.8 & 76.5 & 97.2 & 97.4 & 74.01 & 80.2 & $89.7 \pm 15$ \\
\hline $\mathrm{Al}$ & 89.8 & 72.3 & 63.4 & 49.3 & 128.8 & 145.3 & 117.6 & 110.7 & $97.2 \pm 33.9$ \\
\hline $\mathrm{Sr}$ & 84.8 & 74.3 & 32.6 & 23.6 & 30.5 & 31 & 28.1 & 24.9 & $41.2 \pm 24$ \\
\hline Mn & 26.6 & 30 & 198.8 & 197.6 & 61.6 & 62.7 & 78.9 & 99.1 & $94.4 \pm 68.3$ \\
\hline $\mathrm{Cu}$ & 20.9 & 20.6 & 11 & 9.14 & 15.7 & 14.7 & 7.27 & 9.23 & $13.6 \pm 5.3$ \\
\hline B & 8.88 & 8.51 & 7.84 & 9.93 & 7.16 & 7.94 & 4.05 & 4.69 & $7.38 \pm 2.03$ \\
\hline $\mathrm{Cr}$ & 2.44 & 2.56 & 2.39 & 2.24 & 2.7 & 2.4 & 1.38 & 2.08 & $2.27 \pm 0.41$ \\
\hline $\mathrm{Ba}$ & 2.32 & 2.24 & 1.48 & 1.9 & 1.59 & 1.32 & 1.22 & 1.3 & $1.67 \pm 0.43$ \\
\hline V & 1.08 & 1.02 & 0.66 & 0.61 & 1.06 & 0.89 & 0.42 & 0.73 & $0.81 \pm 0.24$ \\
\hline $\mathrm{Pb}$ & 0.93 & 1.6 & 1.23 & 0.95 & 1.45 & 1.16 & 0.73 & 0.89 & $1.12 \pm 0.30$ \\
\hline $\mathrm{Cd}$ & 0.67 & 0.7 & 0.69 & 0.59 & 0.74 & 0.81 & 0.72 & 1.03 & $0.74 \pm 0.13$ \\
\hline Co & 0.02 & 0.14 & 0.11 & 0.12 & 0.21 & 0.18 & 0.43 & 0.71 & $0.24 \pm 0.22$ \\
\hline
\end{tabular}

Content of some trace metals and in particular $\mathrm{Zn}$ and $\mathrm{Cu}$ was also relatively high - about $89.7 \pm 15 \mathrm{mg} \cdot \mathrm{kg}^{-1}$ and $13.6 \pm 5.3 \mathrm{mg} \cdot \mathrm{kg}^{-1}$ respectively. Meanwhile, much less $\mathrm{Pb}(1.12 \pm$ $\left.0.3 \mathrm{mg} \cdot \mathrm{kg}^{-1}\right)$ and $\mathrm{Cd}\left(0.74 \pm 0.13 \mathrm{mg} \cdot \mathrm{kg}^{-1}\right)$ was found in the samples. The content of these chemical elements is comparable to other species of the genus Deschampsia (Höhne et al., 1981). However, due to the lack of permanent settlements and, therefore, much less polluted environment in the Antarctic, we considered that the content of trace elements in the leaves of D. antarctica possibly should be lower. Future studies are needed to find out whether D. antarctica may be a hyperaccumulator of trace metals (Jankowski et al., 2019). Our preliminary results support the idea that this species may be suitable for biomonitoring.

Surprisingly, the content of $\mathrm{Mn}$ in the leaves varied considerably: from just 26.6 - $30.0 \mathrm{mg} \cdot \mathrm{kg}^{-1}$ in the samples from Oasis
Rasmussen up to almost $200 \mathrm{mg} \cdot \mathrm{kg}^{-1}$ in the samples from Great Yalour Island. Though $\mathrm{Mn}$ is not a toxic element in general, it is well known for being phytotoxic under certain edaphic and climatic conditions (Fernando \& Lynch, 2015). This topic deserves greater research attention in the context of major differences between the samples from different locations and potential effects that they may have on other plants.

One of the probable reasons for such differences may be the heterogeneity of soil properties in the maritime Antarctic. Parnikoza et al. (2016) reported that the content of toxic elements in the soils of Galindez Island varied greatly, and the highest content of trace metals was in the soils located close to the station facilities. For example, the content of $\mathrm{Cu}$ varied from 0.2 to $70.0 \mathrm{mg} \cdot \mathrm{kg}^{-1}$ in the soils without visible human impact, reached $192.5 \mathrm{mg} \cdot \mathrm{kg}^{-1}$ near the main building of Vernadsky station, and 
over $1850 \mathrm{mg} \cdot \mathrm{kg}^{-1}$ in soils near power facilities (diesel generators). Content of $\mathrm{Pb}$ varied from 3.1 to $63.8 \mathrm{mg} \cdot \mathrm{kg}^{-1}$ in most of the studied soils but was considerably higher - 741.3 $\mathrm{mg} \cdot \mathrm{kg}^{-1}$ and $1760.0 \mathrm{mg} \cdot \mathrm{kg}^{-1}$ in the soils close to power generators and main station building respectively. Therefore, the anthropogenic impact may strongly affect the content and composition of the Antarctic soils, and this fact should be taken into account in future research focused on the bioindicative role of D. antarctica. Another possible reason for the uneven distribution of trace elements, including trace metals, is a strong zoogenic impact on the coastal soils in the maritime Antarctic and sub-Antarctic regions. Boelhouwers et al. (2008) highlighted that "in the coastal areas the erosion, transport and deposition of sediment by wild animals may play a dominant role in shaping sections of the landscape" (p. 83). That impact includes, but is not limited to, accumulation of guano. Bedernichek et al. (2020) reported that seal hair and other byproducts contain a lot of biogenic and toxic elements. The accumulation of hair, skin, carcasses of sea mammals on the soil, as well as their urine and excrements, may also be one of the key factors that affect the elemental composition of the coastal soils in Polar regions.

Due to the small sample size in this study, it is too early to discuss possible reasons for the differences found between the plant samples, as well as their significance. However, the findings suggest that the leaves of D. antarctica contain a lot of biogenic elements. This fact confirms that this plant is a substantial and rich in nutrients precursor of soil organic matter, and is important in the context of soil formation and development in the maritime Antarctic (Parnikoza, 2019). Also, due to relatively high concentrations of trace metals and their variability between the sample plots, we hypothesize that leaves of $\mathrm{D}$. antarctica may be used as an informative bioindicator. Future research with enough replicates is needed to confirm these preliminary results and hypotheses.

\section{Acknowledgements}

This study was supported by the State Institution "National Antarctic Scientific
Center"; the project "Impact of seabirds on soil formation and development in Maritime Antarctic" (0118U100403). We also are grateful to the anonymous reviewers whose comments significantly improved the previous version of the manuscript.

\section{References}

Bedernichek, T., Dykyy, I., Partyka, T., \& Zaimenko, N. (2020). Why WRB needs a mammalic qualifier: the case of seal colony soils. Geoderma, 371. https://doi.org/10.1016/j. geoderma.2020.114369

Biersma, E. M., Torres-Díaz, C., MolinaMontenegro, M. A., Newsham, K. K., Vidal, M. A., Collado, G. A., Acuña-Rodríguez, I. S., Ballesteros, G. I., Figueroa, C. C., Goodall-Copestake, W. P., Leppe, M. A., Cuba-Díaz, M., Valladares, M. A., Pertierra, L. R., \& Convey, P. (2020). Multiple latePleistocene colonisation events of the Antarctic pearlwort Colobanthus quitensis (Caryophyllaceae) reveal the recent arrival of native Antarctic vascular flora. Journal of Biogeography 00, 1-11, https://doi. org/10.1111/jbi.13843

Boelhouwers, J., Meiklejohn, I., Holness, S., \& Hedding, D. (2008). Geology, geomorphology and climate change: land-sea interactions in a changing ecosystem. In S. Chown, P. W. Froneman (Eds.), The Prince Edward Islands: land-sea interactions in a changing ecosystem (pp. 65-96). Sun Press.

Chiapella, J. (2007). A molecular phylogenetic study of Deschampsia (Poaceae: Aveneae) inferred from nuclear ITS and plastid trnL sequence data: Support for the recognition of Avenella and Vahlodea. Taxon, 56(1), 55-64. https://doi.org/ $10.2307 / 25065735$

Chwedorzewska, K. J., Giełwanowska, I., \& Szczuka, E. (2008). High anatomical and low genetic diversity in Deschampsia antarctica Desv. from King George Island, the Antarctic. Polish Polar Research, 29(4), 377-386.

Cuba-Díaz, M., Rivera-Mora, C., Navarrete, E. \& Klagges, M. (2020). Advances of native and nonnative Antarctic species to in vitro conservation: improvement of disinfection protocols. Scientific Reports, 10, 3845. https://doi.org/10.1038/ s41598-020-60533-1

Fabiszewski, J., \& Wojtun, B. (2000). Chemical composition of some dominating plants in the maritime antarctic tundra (King George Island). Bibliotheca Lichenologica, 75(75), 79-91. 
Fasanella, M., Premoli, A. C., Urdampilleta, J. D., González, M. L., \& Chiapella, J. O. (2017). How did a grass reach Antarctica? The Patagonian connection of Deschampsia antarctica (Poaceae). Botanical Journal of the Linnean Society, 185(4), 511-524. https://doi.org/10.1093/botlinnean/ box070

Fernando, D. R., \& Lynch, J. P. (2015). Manganese phytotoxicity: new light on an old problem. Annals of Botany, 116(3), 313-319. https://doi. org/10.1093/aob/mcv111

Fowbert, J. A., \& Lewis Smith, R. I. (1994). Rapid population increases in native vascular plants in the Argentine Islands, Antarctic Peninsula. Arctic and Alpine Research, 26(3), 290-296. https://doi. org/10.2307/1551941

Gidekel, M., Destefano-Beltrán, L., García, P., Mujica, L., Leal, P., Cuba, M., Fuentes, L., Bravo, L. A., Corcuera, L. J., Alberdi, M., Concha, I., \& Gutiérrez, A. (2003). Identification and characterization of three novel cold acclimationresponsive genes from the extremophile hair grass Deschampsia antarctica Desv. Extremophiles 7, 459-469. https://doi.org/10.1007/s00792-0030345-4

Hansen, T. H., De Bang, T. C., Laursen, K. H., Pedas, P., Husted, S., \& Schjoerring, J. K. (2013). Multi-element plant tissue analysis using ICP spectrometry. Methods in Molecular Biology, 953, 121-141. https://doi.org/10.1007/978-1-62703$152-3$-8

Höhne, H., Fiedler, H. J., \& Ilgen, G. (1981). Untersuchungen über den Mineralstoffgehalt von Deschampsia flexuosa (L.) P. B. als Bestandteil von Fichtenforst-Ökosystement. Flora, 171(3), 199-215. https://doi.org/10.1016/s03672530(17)31267-7

Jankowski, K., Malinowska, E., Ciepiela, G. A., Jankowska, J., Wiśniewska-Kadżajan, B., \& Sosnowski, J. (2019). Lead and cadmium content in grass growing near an expressway. Archives of Environmental Contamination and Toxicology, 76(1), 66-75. https://doi.org/10.1007/s00244-0180565-3

Juchnowicz-Bierbasz, M., \& Rakusa-Suszczewski, S. (2002). Nutrients and cations content in soil solutions from the present and abandoned penguin rookeries (Antarctica, King George Island). Polish Journal of Ecology, 50(1), 79-91.
Nuzhyna, N., Parnikoza, I., Poronnik, O., Kozeretska, I., \& Kunakh, V. (2019). Anatomical variations of Deschampsia antarctica É. Desv. Plants from distant Antarctic regions, in vitro culture, and in relations to Deschampsia caespitosa (L.) P. Beauv. Polish Polar Research, 40(4), 361-383. https://doi.org/10.24425/ppr.2019.130903

Ozheredova, I. P., Parnikoza, I. Y., Poronnik, O. O., Kozeretska, I. A., Demidov, S. V., \& Kunakh, V. A. (2015). Mechanisms of antarctic vascular plant adaptation to abiotic environmental factors. Cytology and Genetics, 49(2), 139-145. https://doi. org/10.3103/S0095452715020085

Park, J. H., Day, T. A., Strauss, S., \& Ruhland, C. T. (2007). Biogeochemical pools and fluxes of carbon and nitrogen in a maritime tundra near penguin colonies along the Antarctic Peninsula. Polar Biology, 30(2), 199-207. https://doi. org/10.1007/s00300-006-0173-y

Parnikoza, I. (2019). Ecological mechanisms of Antarctic hairgrass (Deschampsia antarctica É. Desv.) adaptation in Antarctic climate change conditions (Doctoral dissertation). Kyiv: Institute of Molecular Biology and Genetics of the NAS of Ukraine. Retrieved from http://scc.univ.kiev.ua/ upload/iblock/f8d/dis_Parnikoza\%20I.Yu..pdf

Parnikoza, I., Abakumov, E., Korsun, S., Klymenko, I., Netsyk, M., Kudinova, A., \& Kozeretska, I. (2016). Soils of the Argentine Islands, Antarctica: Diversity and characteristics. Polarforschung, 86(2), 83-96. https://doi. org/10.2312/polarforschung.86.2.83

Parnikoza, I., Kozeretska, I., \& Kunakh, V. (2011). Vascular plants of the maritime Antarctic: Origin and adaptation. American Journal of Plant Sciences, 2(3), 381-395. https://doi.org/10.4236/ ajps.2011.23044

Walton, D. W. H., \& Smith, R. I. L. (1979). The chemical composition of South Georgian vegetation. British Antarctic Survey Bulletin, 49, 117-135.

Wu, S., Feng, X., \& Wittmeier, A. (1997). Microwave digestion of plant and grain reference materials in nitric acid or a mixture of nitric acid and hydrogen peroxide for the determination of multi-elements by inductively coupled plasma mass spectrometry. Journal of Analytical Atomic Spectrometry, 12(8), 797-806. https://doi. org/10.1039/a607217h 


\title{
Вміст біогенних та токсичних елементів у листках Deschampsia antarctica É. Desv. (Роaceae): попереднє дослідження
}

\author{
Т. Бедернічек ${ }^{1 *}$, В. Лоя ${ }^{1}$, І. Парнікоза ${ }^{2,3}$
}

${ }^{1}$ Національний ботанічний сад імені М. М. Гришка НАН України, вул. Тімірязєвська, 1, м. Київ, 01014 , Україна, * bedernichek@nas.gov.ua

${ }^{2}$ Національний антарктичний науковий центр МОН України, бульвар Тараса Шевченка, 16, м. Київ, 01601, Україна

3 Інститут молекулярної біології і генетики НАН України, вул. Академіка Заболотного, 150, м. Київ, 03143, Україна

Щучник антарктичний (Deschampsia antarctica É. Desv.) - один із двох аборигенних видів квіткових рослин, поширених у Антарктиці. 3 огляду на це, D. antarctica інтенсивно досліджують упродовж десятиліть, але інформація про вміст біогенних і токсичних елементів в листках цієї рослини $\epsilon$ фрагментарною та потребує уточнення. Оскільки D. antarctica $є$ важливим компонентом екосистем прибережної Антарктики, вміст у рослинах таких біогенних елементів як K, P та S може суттєво впливати на властивості ґрунтів, особливо у ризосфері та детритосфері. Також, вміст у рослинах токсичних елементів, зокрема важких металів, $є$ важливим критерієм оцінки їхньої індикаторної ролі - чи може D. antarctica бути використаний як біоіндикатор для моніторингу стану довкілля в Антарктиці? В цьому повідомленні представлено попередні результати щодо вмісту К, P, Ca, S, Mg, $\mathrm{Na}, \mathrm{Si}, \mathrm{Fe}, \mathrm{Zn}, \mathrm{Al}, \mathrm{Sr}, \mathrm{Mn}, \mathrm{Cu}, \mathrm{B}, \mathrm{Cr}, \mathrm{Ba}, \mathrm{V}, \mathrm{Pb}, \mathrm{Cd}$ та Со в листках D. antarctica з природних місцезростань у прибережній Антарктиці. Сухі листки були озолені в азотній кислоті у мікрохвильовій печі. Концентрації елементів були визначені методом оптичної емісійної спектрометрії 3 індуктивнозв'язаною плазмою. З'ясовано, що відмінності між зразками, відібраними з одного місцезростання були набагато менш виражені, ніж між зразками з різних місцезростань. Серед

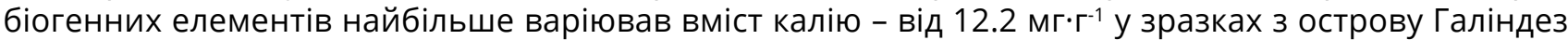
до 28.7 мг $\cdot \Gamma^{-1}$ у зразках з мису Туксен (Антарктичний півострів). Вміст важких металів також значно відрізнявся у зразків з різних локалітетів. Результати цього попереднього дослідження свідчать, що внаслідок високого вмісту біогенних елементів у листках, рослини D. antarctica слід розглядати як важливий прекурсор органічної речовини ґрунту, а також як можливий біоіндикатор. Подальші дослідження необхідні для підтвердження або спростування висловлених у цьому повідомленні припущень. 